\title{
Local Management and New Public Management
}

UDK: 352:005

Irena Bačlija

University of Ljubljana, Faculty of Social Sciences

irena.baclija@fdv.uni-li.si

\section{ABSTRACT}

Economic globalization, growingly differentiated and unstable markets, fiscal crises in light of increasing public expenditure are the elements of an uncertain future for local communities. The latter are captured in the growing demand of users or citizens for quality in public services and in the regulation of the state that (sometimes) limits the creative development and competition on a global market of local communities. In the context of this ever demanding environment functions local administration that has to be reformed in order to conform with the elements of this environment. The article presents the specifics of local management and alongside its reform process by the principles of new public management. Empirical part of the article explains findings of an extensive study of local administrations in the European Union and their reforms with implications that show the effects of reformed local administration on the effectiveness of the entire local community.

Keywords: local administration, new public management, local communities

\section{JEL: D73}

\section{Introduction}

Economic globalization, growingly differentiated and unstable markets, fiscal crises in light of increasing public expenditure are the elements of an uncertain future for local communities. ${ }^{1}$ Some local

1 In its essence local community represents a territorial community of people that satisfy their common needs with common activities. An institution, which defines the status of a local community in legal system terminology, is called local self-government. Analytically local self-government merges two elements: a local community as a sociological element

Bačlija, I. (2011). Local Management and New Public Management.

Uprava IX(4), 117-135. 
communities have preserved themselves as local societies; others lost their structure and have been for longer periods of time subjected to national and international strategies. In any case local communities have to adapt to new circumstances either through innovations in their operation or management or by implementing good practices. The strategy of copying successful public policies and programmes has its roots in the change of a development paradigm in the 70's and 80's (Harvey, 1989; Keating, 1998; Brenner, 1999). Before that only two distinctive types of governmental functions were in use - production and consumption. The national level had the function of production and local communities took care of consumption with which they ensured continual manpower (O'Connor, 1973; Saunders, 1986; Harvey, 1989; Harding, 2005). Globalization effects have caused increasing proactive role of local communities that started planning their own development. Local authorities, even those from different socio-political environments, encountered with the same challenge of economic development and their answer were similar innovative policies (Mayer, 1995; Porter, 1998; Harding, 2005).

Bramezza (1996) believes that the response of local communities to global influences can differ because of predispositions (historical, legislative, macro-economical) and environment (political, economical, administrative), but a certain type of managing local communities that enables optimal use of potential predispositions and environment, does exist. This opinion is shared also by Pollitt and Bouckaert (2004, p. 8), saying that from external systematic influences, which caused the reforms in the public sector, it is possible to conclude that the reform process of the same kind of organizations (local administration organizations) took its course by the same principles. The prevailing principle for modernizing local management (as a response to global changes) is the implementation of concept(s) of New Public Management (NPM). NPM principles and tools are in extensive use at the local level. On the basis of empirical study Daeman and Schaap (2000, p. 175) proved that the NPM tools at local level in EU are in general use and similar applies for some

and local self-government as an element of the legal system. Self-government must be formally granted or recognized to the local community by the state. As such it has some characteristics, with which it can be separated from the state administration. Vlaj (1992) claims the following: autonomy, independence, decentralization and democratization which all give local communities the right to jurisdiction over public affairs that are of local importance.

118 Uprava, letnik IX, 4/2011 
cities in the USA (New York (Weikart, 2001), Milwaukee (Norquist, 1998) and Indianapolis (Goldsmith, 1998)) and around the world (Prohl, 1997).

The article is organised on two focal points. First that local management in post-Weberian era has special significance because more and more tasks are devolved to the local level. It has to face increase in workload alongside with competing for financial resources and compete in the global market of local communities. Local administration also acts in the context of this demanding environment and has to be reformed in order to be successful. And in the second part, the article presents the results of the study of local administration modernization in the case of 58 cities in the European Union (EU). Previous (though rare) research of local administration modernization by the NPM model (Hambleton, 2004; Daeman \& Schaap, 2000; Weikart, 2001; Norquist, 1998; Goldsmith, 1998; Prohl, 1997) has shown that reforms are being carried out but they have not answered the key question - does reformed management have an actual influence on the whole local community. In this extent the concluding part of the paper explains statistical correlations between NPM index and a) population of the local community, b) average GDP of the local community, c) Power Index and d) the Lisbon benchmark. Indicated correlations can offer an answer to actual effects of local administration reforms and with that a convincing argument for further encouragements of similar processes.

\section{Global influences on local management}

Local management is in many ways different than management in general (considering mostly management on the national level and not so much management in the private sector). There are multiple reasons for this. Local administration and local government are closer to the user (citizen) and can be more responsive and adaptable to their needs. On the other hand local governments are greatly limited with national legislative frameworks that (can) suffocate development and creativity of leadership and management and with that the effectiveness of an individual local community. In such a manner local management has to be even more inventive and creative, so that it can on one hand respond to direct pressures from its citizens and efficiently "steer" inside the limitations that are given by the state. As well as the push-pull effect that is created by the citizens and the state regulation, local management is also influenced by global trends. The latter can be presented in the scope 
of three global movements/phenomena: globalization, neo-liberalism and the wave of decentralization. These ideas intersect with each other in certain points. So it is often unclear what is a consequence of neoliberalism and what is a consequence of globalization. It also has to be taken into consideration that NPM, being a consequence of neoliberalism, includes decentralization.

Globalization can also be understood as the pressures from global corporative elites to reduce the role of the welfare state or to reduce the role of the state in general (Habermas, 1991; Offe, 1985). Some believe that the independence of multinational corporations from any national state leads to redundancy of the states in general (Ball, 1967; Naisbitt, 1994). For Stever (1988) globalization means the end of the public sector, but for Rifkin (1996) it represents the end of labour. On the other hand Brezovšek \& Črnčec (2007, pp. 28) conclude that globalization did not cause the end of the state and its administration (bureaucracy) and that this will not happen in the near future because relations between market and policy, capitalism and state, public and private sector are interdependent. Globalization also influences administrative systems of individual states, which are enforced with the possibilities of information technology and requests for better efficiency. All of these pressures influence the structure of administrative systems, their autonomy and management methods. Within this larger centralization (so the state can be more easily involved into supranational administrative networks) or larger decentralization (so non-state actors could become a part of the global action) is requested. Korten (1995) believes that globalization threatens local communities because it reduces local supervision and relevancy of local participation (and with that democracy). It consequently reduces the role of citizens and also the role of local civil servants on making decisions, which are important for the local environment (Farazamand \& Bevir, 2007). Multinational corporations can endanger the financial sustainability of the local budget if withdrawing the transfers of production or their headquarters. The task of the local administration is therefore to reduce the financial uncertainty with establishing long-term partnerships with multinational investors.

Neo-liberal reform of the public sector has its roots in the 70's (the first wave manifested into NPM). Presumption was that with the reduction of the role of administration and the entry of some private businesses into the process of ensuring public services, economic growth should occur 
and service efficiency should increase. Based on economic neoclassical theories a reform wave was triggered in 80 's and there were attempts to implement these new theories and findings (Hughes, 2003). Changes for the local communities, caused by neo-liberalism, are categorized by Brener and Theodore (2002) as the reduction of state financial support for ensuring public services, devolution of new tasks as well as formation of mechanisms for rewarding and co-financing business-like behaviour. It also promoted shift from bureaucratically organized local administration to privatization of public services, creation of private-public partnerships and acting on the principles of NPM. Neo-liberalism encouraged formation of new institutional bypasses, through which economic elites can directly influence on important development decisions. Special business zones are created (for example technology parks), investor taxes are reduced and the function of performance at the global market of local communities is emphasized.

Simultaneously local management is influenced by decentralization (transfer of authority from the national to the local level). Some authors see decentralization as a necessary step towards greater democratization (Diamond, 1999; Huther \& Shah, 1998; Fox, 1994), for others it is a way of a more effective and efficient public services provision (Tiebout, 1956; Prud'homme, 1995; Stein, 1998; Tanzi, 1994). Kroukamp \& Lues (2000) believe that the wave of democratization was caused by modernization of national administration, democratization and economic pressures, which demanded a more efficient way of public services provision. Due to neoliberal pressures and demands for a lean state, a great deal of public services has been transferred to local authorities. Approach to decentralization is (was) different in each country and depends upon different circumstances (institutional framework, economic stability, historical experiences, civil society needs and similar). Experiences of the previous two decades show that decentralization is used in almost all countries around the world (Dillinger \& Fay, 1999).

\subsection{Ensuring public services - the prevailing function of local communities}

Public services provision at the local level is a function that originates from decentralization. Decentralization transfers public service provision by subsidiarity to the lowest possible local level, which is still able to perform public service of certain quality. Such understanding of authority 
transfer brings about three main advantages. First local authority is closest to the citizens and therefore understands and identifies their needs best. Secondly, the flexibility of local political decision-making enables adaptation to local conditions and changes in demand for public services. Last but not least the advantage is that because of the political responsibility of local authorities' public services provision is more efficient.

The wave of decentralization in the 80's devolved a substantial share of public service provision to the local level. From the 19th century onwards local authorities became more and more involved in an increasing number of tasks, like water supply, sewage system, gas supply and similar. Which later led up to a wider spectre of public services that the local communities should have provided (health care, school system, public transportation etc.) (ECOTEC, 2007). Despite considerable variation in local-government structures, the pattern of municipal responsibility in pre-1945 Europe was broadly similar across the continent. After 1945, the development of welfare states and collectivisation in much of Central and Eastern Europe resulted in governments as a whole assuming responsibility for a far greater number of tasks. Perhaps, the next major challenge to the status quo in urban government came with the rise of a neo-liberal political agenda and the development of New Public Management theories from the 1980s onwards. The policies associated with the new economic and social doctrine, which challenged the post war settlement, were pioneered and most vigorously pursued in the United Kingdom. That again led to the erosion of the service function of local communities. The last visible change, that was responsible for jurisdiction transference, was the reform of local self-administration in East- and Central-European countries after 1989. That is when local communities gained actual jurisdictions for the execution of public services. Before that they were only performing directives of national governments (ibidem).

\section{Reforming management - NPM}

Because of the before mentioned pressures to local communities (more and more transferred tasks and competition for financial resources - from the state and from investors) local management is becoming the element, with which a community can successfully provide public services and enable community development. It should be noted that in this 
context post-Weberian management types are proposed. Despite many criticism NPM remains as one of the most recognized prevailing modern management paradigms.

Introduction of NPM principles is related to a new, modern working process organization, to the definition and delimitation of responsibility, especially definition of responsibility for results, to increase organization and individual autonomy and the reduction of the levels in the organization structure (Žurga, 2001). NPM is therefore a fusion of traditional public administration normative orientation and the instrumental orientation of business management. We can see management as a new form of state business management in an area, which used to "belong" to administration, but in a different way and with different emphasis (Dunleavy and Hood, 1994). Societal changes, which conditioned the NPM paradigm, occurred in the 70's. Conservative economists argued that the government and its administration were an economic problem, which limited economic growth and freedom. By reducing the role of administration and the entry of some private corporations in the process of public services provision a more effective service as well as economic growth should be accomplished. On the basis of economic neoclassical approaches a new wave of reforms was triggered in 80s. They tried to implement new economic theories and recognitions into the operation of public administrations (Hughes, 2003). Public administration reforms manifested in different forms. Flynn and Strehl (1996) believe that the foundation for differentiating administration lies in constitutional arrangements, political opinion on the national and local level, public relation to the administration and to those employed in administration, skills and knowledge of public sector managers, ideological and political beliefs as well as administrative culture. Further they claim that countries with a strong central government implement reforms much easier because of their supervision over public administration. In countries where local administration and state administration are more equal and local administration has certain autonomy and constitutional protection, reforms are more difficult to carry out.

The wide spectre of reform manifestation in different countries opened the door to numerous critics, which believed that NPM is not a paradigm because its realization is not unified and therefore it is not necessary that it originates from the same social effects. Brezovšek and Bačlija (2010) 
establish three central points of critics. The first is that NPM represents "emperor's new clothes", meaning only excitement and no content. Because of taking over a wide spectre of management tools from the private sector, some authors of NPM added some tools based on their personal judgment or completely neglected others. ${ }^{2}$ In this context NPM lost the battle of "recognisability" as it was all and nothing at once. And it did not give answers to some old dilemmas or problems of management. The second criticism is connected with the findings of administration reform evaluation, which in some countries revealed that NPM was not able to reduce costs per unit of public service/good (Hood, 1991). As such the reform was not able to fulfil its main promise and its main consequences of "management praise" go without tangible results. With the help of some measures to reduce financial sources for public organizations, in the opinion of some (Nethercote, 1989), they attained only system instability and not measurable final results. The third frequent criticism is that NPM does not speak in favour of public good but that it is a lever for satisfying particularistic interests. NPM should therefore be only a tool of such administrative elite, which desires to usurp even more power and desires to progress in the civil service system.

\subsection{NPM at the local level}

Alongside different manifestations of NPM paradigm in different national systems it is expectable that there are differences on the national - local line of separation. But the question still remains if we can discuss general guidelines of NPM at the local level or are there about as much (if not more) manifestations of NPM, as there are self-administrative systems. Nevertheless some authors predict that some general guidelines of local level NPM can be drawn, although this is not backed up by empirical evidence.

Stoker (1996) prepared an attempt of presenting influence of NPM on the local level (see table 1). It is clear that simultaneous (or as a consequence of NPM) de-centralisation or de-concentration of services has influenced a certain increase in the level of autonomy for

2 Kettl (1995, p. 14) for example believes that „NPM includes contradictive goals«, Ferlie et al. (1996, p. 10) see "new public management as an empty canvas ... you can paint anything on it«. Beside that the paradigm is differently interpreted that consequently leads to inconsistencies, for example »public managers have more discretion« (Kaboolian, 1998) and »public employees are limited in discretion« (Barberis, 1988).

124 Uprava, letnik IX, 4/2011 
self-administrative communities, although we always must critically doubt about the actual autonomy. So the main focus of NPM at the local level is oriented especially towards the quality of services and economy. The proximity and nature of the local community make the citizen a more important user of public services, which can bring together traditional and consumer participation methods.

Table 1: Local authority operation in the framework of NPM

\begin{tabular}{|l|l|l|}
\hline & $\begin{array}{l}\text { Local authority after the II. World } \\
\text { War }\end{array}$ & $\begin{array}{l}\text { Local authority in the framework of } \\
\text { the new public management } \\
\text { paradigm }\end{array}$ \\
\hline $\begin{array}{l}\text { Guidance of local } \\
\text { authorities }\end{array}$ & $\begin{array}{l}\text { Input management, ensuring public } \\
\text { services in the context of a welfare } \\
\text { state }\end{array}$ & $\begin{array}{l}\text { Input and output management } \\
\text { taking into consideration the } \\
\text { principle of effectiveness, efficiency } \\
\text { and responsiveness towards citizens }\end{array}$ \\
\hline Prevailing ideology & Professionalism and party affiliation & Management and consumerism \\
\hline $\begin{array}{l}\text { Definition of public } \\
\text { interest }\end{array}$ & $\begin{array}{l}\text { Politicians and experts - citizens do } \\
\text { not participate }\end{array}$ & $\begin{array}{l}\text { Aggregate of individual interests, } \\
\text { which manifests in the user's choice }\end{array}$ \\
\hline $\begin{array}{l}\text { Prevailing } \\
\text { responsibility } \\
\text { model }\end{array}$ & $\begin{array}{l}\text { Democracy; elections, elected } \\
\text { political officials with a given } \\
\text { mandate, tasks are performed } \\
\text { through bureaucracy supervision }\end{array}$ & $\begin{array}{l}\text { Separation of politics and } \\
\text { management; politics gives } \\
\text { directions, but does not supervise } \\
\text { the process of implementation and } \\
\text { is an additional protection in the } \\
\text { form of service user supervision } \\
\text { (feedback) }\end{array}$ \\
\hline $\begin{array}{l}\text { System of ensuring } \\
\text { public services }\end{array}$ & $\begin{array}{l}\text { Hierarchical and sector-oriented } \\
\text { organization }\end{array}$ & $\begin{array}{l}\text { Private sector or quasi-public } \\
\text { institutions (quangos) }\end{array}$ \\
\hline
\end{tabular}

Source: Stoker (1996).

By all means Stoker (ibidem) points out the prevailing service function of the local level and the proximity between citizens and local authorities, which distinguishes administration reforms on the local level from administration reforms on the national level. At the same time before mentioned critics of NPM should not be overlooked, because the same analogy can be applied to NPM at the local level.

\subsection{Empirical research}

We have already established that empirical research (above all appropriate qualitative) on the implementation of NPM is few and far between in general and even less at the local level. Exceptional research does show a wider implementation of the public sector on the city level (Hambleton, 2004). Daeman and Schaap (2000, p. 175) for example, have proven on the sample of 15 cities, that NPM tools at the local level 
in Europe are in general use. Based on this information we have analysed the implementation of NPM in 58 cities $^{3}$ across the EU. We surveyed the highest ranked civil servants in the local administration hierarchy (in Slovenia the title Director of Municipal Administration is suitable).

Quantitative assessment of the implementation of a wide range of NPM tools and mechanisms is highly difficult. Therefore we have used the indicators proposed by Brudney, Hebert and Wright (1999, p. 22), measuring the implementation of the NPM paradigm with the following indicatiors:

- training programmes to improve client or costumer service,

- quality improvement programmes (courses, trainings, workshops and similar) for promoting teamwork and solving problems,

- benchmarks for measuring program outcomes or results,

- strategic planning, that produces clear agency mission statements,

- simplification and relaxation of human resource (personnel) rules,

- privatization of major programmes,

- reduction in the number of levels in the agency hierarchy.

Based on those indicators we have prepared the NPM index. This index is a sum of recoded values of the answers ${ }^{4}$ and is the base for the assessment of an individual city administration reform level.

Furthermore we wanted to check if the implementation of NPM is in any way related to some characteristics of the local community (for example size, total resident population, economic effectiveness etc.). This could in fact provide answer to the question, does NPM have any actual measurable implications in real environment? For this purpose we merged

3 Aarhus, Antwerp, Banska Bystrica, Bialystok, Birmingham, Bonn, Bordeaux, Breda, Brescia, Brno, Brugge, Brussels, Budapest, Bydgoszcz, Cagliari, Ceske Budeovice, Debrecen, Edinburg, Eindhoven, Essen, Gent, Glasgow, Graz, Helsinki, Innsbruck, Kielce, København, Krakow, Le Havre, Leeds, Liberec, Limerick, Linz, Ljubljana, Luxemburg, Madrid, Malmö, Maribor, Modena, Nice, Oulu, Plzen, Poznan, Reggio di Calabria, Riga, Rotterdam, s\Gravenhage, Stockholm, Szeged, Tallinn, Tartu, Uppsala, Utrecht, Venice, Verona, Vigo, Vilna, Wroclaw.

4 For answers: no changes considered; considered, no action yet and action(s) planned ranked as a value of zero; for answers: partially implemented and fully implemented we ranked as a value of one. The highest NPM index value is seven. Index classification is as follows: $0-2=$ no reform; $3-5=$ first phase of reform; $5-7=$ reform is in place.

126 Uprava, letnik IX, 4/2011 
our data with Urban Audit ${ }^{5}$ data. To calculate some other values (for example GDP per capita looking at the national average and the average unemployment rate in the city in relation to national average) we used Eurostat $^{6}$ databases as well. In the final phase of the research we processed the gathered data with the computer software SPSS, where we joined answers and variables from the Urban Audit database in the same matrix.

\subsection{Results}

After recoding and categorizing data we can conclude that $21.1 \%$ of observed local administration have not been reformed, $45.6 \%$ are in the first phase of reform and $22.8 \%$ are reformed $110.5 \%$ of respondents did not answer this question). From table 2 we can see that the introduction of strategic management for defining clear goals (average value 3.69) and the education of employees for public service improvement (average value 3.60) are the most common implemented elements of the NPM. The least used are the reduction of hierarchical levels in local administration (average value 2.38) and the privatization of larger public programmes (average value 2.52). These results are somewhat surprising, not so because of the percentage of local administrations, which implemented NPM elements, but more because of the elements, that are most commonly introduced. Neo-liberalism, which manifested also in the NPM paradigm, tries to reduce the role of administration and promote privatization of public service provision (Hughes, 2003). But our research shows that city administrations in the $\mathrm{EU}$ do not use the principle of privatization very often.

5 Empirical data, which were later joined with empirical data from our research, have been gained from Urban Audit databases (Urban Audit databases are accessible via website http://www.urbanaudit.org/index.aspx).

6 We compared city condition based on the national average (as a deviation in the positive or negative direction based on national average) to limit the influence of national environments on the values of individual variables. That is why we completed the databases with Eurostat databases (http://epp.eurostat.ec.europa.eu/portal/page/portal/ eurostat/home/) and with that assessed city effectiveness in relation to national environment. Thus we removed or at least limited errors in measurement. 
Table 2: Local administration reform regarding individual NPM elements

\begin{tabular}{|l|c|c|c|c|c|c|c|}
\hline & $\begin{array}{c}\text { no changes } \\
\text { considered }\end{array}$ & $\begin{array}{c}\text { considered, } \\
\text { no action yet }\end{array}$ & $\begin{array}{c}\text { action(s) } \\
\text { planned }\end{array}$ & $\begin{array}{c}\text { partially } \\
\text { implemen- } \\
\text { ted }\end{array}$ & $\begin{array}{c}\text { fully } \\
\text { implemen- } \\
\text { ted }\end{array}$ & $\begin{array}{c}\text { average } \\
\text { (scale from } \\
\text { 1 to 5) }\end{array}$ & $\begin{array}{c}\text { standard } \\
\text { deviation }\end{array}$ \\
\hline $\begin{array}{l}\text { educational } \\
\text { programmes for } \\
\text { improving public } \\
\text { services }\end{array}$ & 11.5 & 1.9 & 9.6 & 40.4 & 30.8 & 3.60 & 1.524 \\
\hline $\begin{array}{l}\text { training for } \\
\text { teamwork and } \\
\text { team problem } \\
\text { solving }\end{array}$ & 9.6 & 9.6 & 15.4 & 34.6 & 25.0 & 3.38 & 1.497 \\
\hline $\begin{array}{l}\text { benchmarking for } \\
\text { better assessment } \\
\text { of our products }\end{array}$ & 11.5 & 7.7 & 11.5 & 46.2 & 13.5 & 3.13 & 1.560 \\
\hline $\begin{array}{l}\text { strategic } \\
\text { planning, which } \\
\text { sets clear goals of } \\
\text { the organization }\end{array}$ & 7.7 & 5.8 & 5.8 & 42.3 & 32.7 & 3.69 & 1.476 \\
\hline $\begin{array}{l}\text { simplification of } \\
\text { personnel rules }\end{array}$ & 21.2 & 5.8 & 21.2 & 36.5 & 9.6 & 2.90 & 1.485 \\
\hline $\begin{array}{l}\text { privatization of } \\
\text { major } \\
\text { programmes }\end{array}$ & 26.9 & 15.4 & 15.4 & 25.0 & 9.6 & 2.52 & 1.540 \\
\hline $\begin{array}{l}\text { reduction in the } \\
\text { number of levels } \\
\text { in the hierarchy }\end{array}$ & 34.6 & 23.1 & 13.5 & 7.7 & 17.3 & 2.38 & 1.549 \\
\hline
\end{tabular}

Source: Bačlija (2010) (N = 58).

The next step is an analysis of statistical correlations between the NPM index and independent variables. With Pearson coefficient (see table 3) we can establish the indication of some correlations. It is indicated that NPM correlates with the number of inhabitants, with the average employment rate, with the Lisbon benchmark and with power of the city. This could mean that the bigger the city, more competitive it is and more NPM elements have been implemented by the city administration. But if we use multi-variable analysis - linear regression, it becomes clear that the correlations are no longer the same or in other words that some variables have more influence than others (see table 3). The interpretation of correlation coefficients (beta) suggests, that densely populated cities have implemented less NPM elements. This is in contrast with our expectations. It could be concluded that the denser populated the city is, more work it has on the operative level with ad hoc problems and that obviously leaves less time for systematic improvements.

128 Uprava, letnik IX, 4/2011 
Table 3: Correlations between variables (Pearson coefficient and beta coefficient)

\begin{tabular}{|l|l|}
\hline & NPM index \\
\hline Number of inhabitants & $\begin{array}{l}P=0.312\left(^{*}\right)(\text { sig. }=0.024) \\
B=0.019(\text { sig. }=0.940)\end{array}$ \\
\hline Average GDP per capita & $\begin{array}{l}P=.317\left(^{*}\right)(\text { sig. }=0.038) \\
B=0.398(\text { sig. }=0.150)\end{array}$ \\
\hline Power index & $P=0.264($ sig. $=0.088)$ \\
& $B=0.159($ sig. $=0.508)$ \\
\hline Lisbon benchmark & $P=0.240$ (sig. $=0.147)$ \\
& $B=0.381$ (sig. $=0.094)$ \\
\hline
\end{tabular}

* The correlation is typical with a 0.05 standard error.

Source: Bačlija (2010).

The second indicated statistical correlation is between the implementation of NPM principles and the average GDP per city inhabitant. From that we could assume that wealthier cities are more in favour for administration modernization. The last shown correlation is the correlation between NPM and the Lisbon benchmark. That is actually a very satisfying result, because it means that the local administration reform process and the capability of local communities for creating a highly

7 The influence of individual community local authorities on community effectiveness is highly dependent on the power of the local authority. Based on that, Urban Audit (on city level - Power index of the city) prepared the "power index", which contains multiple indicators, like for example: local authority autonomy at expenditure; local authority autonomy at taxation and the share of national GDP, which is intended for local selfgovernment. The index tries to simulate, how powerful the local self-government is inside an individual national system. (Urban Audit, 2004).

8 The Lisbon benchmark is an index, which assesses the realization of the Lisbon strategy and it is closely connected with the competitiveness of an observed entity. It contains the following variables:

- GDP in relation to the entire population,

- work productivity (GDP per employed person);

- employed residents (the share of employed persons between 15 and 64 years of age);

- employment level of senior workers (share of employed between 55 and 64 years of age);

- long-term unemployment of the elder population (share of those that are unemployed for more than 1 year and are between 55 and 64 years of age);

- share of residents that are currently included in the higher education and university system (share of residents between 15 and 24 years of age, that are currently included in the higher education and university system in relation to the entire population);

- youth unemployment (share of young people between 15 and 24 years of age, which have been unemployed for at least six months). (Urban Audit, 2004) 
competitive and socially stable environment (mostly because of employability), are related. Local administrations therefore have a certain role in the successful and effective operation of local communities.

\section{Conclusions}

Undoubtedly globalization, decentralization and neo-liberalization currents have strongly influenced the way local community administrations operate (Judd \& Parkinson, 1990; Harding, 2005; Dunford \& Kafkalas, 1992; Le Gales, 1998). These are under the growing pressure of ensuring more and more citizen services, which are being transferred from the national level. At the same time the demands of citizens are increasing due to the influence of private sector service influence. Besides that local communities also compete on the global market for investors. This poses as an additional burden for local administration, because they operate in a rapidly changing, almost business-like environment. Managerial tasks at the local level are very demanding and that can be very illustratively shown with a part of a column in a daily newspaper in Ljubliana: »l just expect that some basic things in life operate: that the lights turn on, that the water runs out of the tap and similar. In short - the existence of areas in Ljubliana, where people do not have a sewage system and the waste management is primitive, simply frustrates me. In some other environment or in some other times I perhaps just would not mind." 9

It is necessary for local administrations to reform, so that they can successfully face all challenges. Either they do that by implementing NPM or by any other reform method. Although NPM showed itself as a (too) extensive concept (as Ferlie et al. (1996, p. 10) describe it "as an empty canvas ... you can paint anything on it«) and being the target of multiple critics, it still remains one of the more recognizable and most frequently used method for administration reform. Although Hambleton (2004, p. 20) believes that the NPM paradigm is an insufficient answer to the problems of local communities because of its narrow view on public services and neglect of the institution's democratic vitality, we cannot completely agree with him. Our presumption is that the specifics of local management (orientation to services, user proximity, fast responsiveness of administrative authorities) make NPM, somewhat a neo-Tayloristic method

9 Marjeta Bogataj, Žurnal, $14^{\text {th }}$ of February, 2009. 
with the introduction of rational work method into the public sector, suitable for local administrations.

The presented research confirms our beliefs to some extent. With the help of NPM principles a good part of local communities in the EU is now reformed. For more precise data more extensive studies should have been performed. That would direct future (greatly needed) attention of the academic and professional public to this "undernourished" field of expertise. In any case it pays dividend to follow encouraging results, which show "profit" in the reform of local administrations. Positive effects are being shown for the entire local community, for its strategic development and its financial welfare. Argumentation of the positive effects of administrative reform promotes further popularization of similar processes.

Irena Bačlija, Ph.D. is an assistant professor at the Department of political science at the Faculty of Social Sciences (University of Ljubliana) and a research fellow at the Centre for the Analysis of the Administrative-Political Processes and Institutions. She teaches post-graduate courses "Local management" and "Administrative culture" and assists in the teaching process at several courses of pre-graduate study in Political science Policy analysis and public administration. She has published many scientific articles, papers and books in domestic and foreign publications. 


\section{References}

- (2007). Evaluation of mechanisms for the dissemination and exploitation of the results arising from programmes and initiatives managed by the Directorate-General for Education and Culture. ECOTEC. London: Priestley House.

- Bačlija, I. (2010). Urbani menedžment: koncept, dimenzije in orodja. Ljubljana: Fakulteta za družbene vede.

- Ball, G. (1967). Cosmocorporations: The Importance of Being Stateless. Atlantic Community Quarterly 6(2), 163-170.

- Barberis, P. (1988). The new public management and a new accountability. Public Administration 76(3), 451-470.

- Bramezza, I. (1996). The competitiveness of the European city and the role of urban management in improving city's performance. Hag: CIP-Data Koninklijke Bibliotheek.

- Brenner, N. \& Theodore, N. (2002). Spaces of Neoliberalism: Urban Restructuring in Western Europe and North America. Oxford, Boston: Blackwell.

- Brenner, N. (1999). Globalisation as reteritorialisation: the re-scaling of urban governance in the European Union. Urban Studies 36(3), 431-451.

- Brezovšek, M., \& Bačlija, I. (2010). Sodobna upravna misel. Ljubljana: Fakulteta za družbene vede.

- Brezovšek, M., \& Črnčec, D. (2007). Demokratična uprava in tajnost podatkov. Ljubljana: Fakulteta za družbene vede.

- Brudney, J., Hebert, T. F., \& Wright, D. S. (1999). Reinventing Government in the American states: Measuring and Explaining Administrative Reform. Public Administration Review 59(1), 19-30.

- Daemen, H., \& Schaap, L. (2000). Citizen and City: Developments in Fifteen Local Democracies in Europe. Rotterdam: Erasmus University.

- Diamond, L. (1999). Developing democracy: Toward consolidation. Baltimore: Johns Hopkins University Press.

- Dillinger, W. \& Fay, M. (1999). From Centralized to Decentralized Governance. Finance and development 36(4), 11-16.

- Dunford, M., \& Kafkalas, G. (1992). Cities and Regions in the New Europe. London: Belhaven Press.

- Dunleavy, P. \& Hood, C. (1994). From Old Public Administration to New Public Management. Public Money \& Management 14(3), 9-16. 
- Farazamand, A. (2007). Globalization and Public Administration. V: Bevir, M. (Ed.) Public governance (20-44). London: Sage.

- Ferlie, E. \& Pettigrew, A. (1996). Managing Through Networks: Some Issues and Implications for the NHS. British Journal of Management 7(1), 81-99.

- Flynn, N. \& Strehl, F. (Eds.) (1996). Public Sector Management in Europe. New Jersey: Prentice Hall.

- Fox, J. (1994). Latin America's emerging local politics. Journal of Democracy 5(2), 105-116.

- Goldsmith, M. (1998). European Integration and Local Governments. Aldershot: Edward Elgar Publishers.

- Habermas, J. (1991). The structural transformation of the public sphere: an inquiry into a category of bourgeois society. Cambridge: The MIT Press.

- Hambleton, R. (2004). Beyond New Public Management - city leadership, democratic renewal and the politics of place. City Futures International Conference. Chicago.

- Harding, A. (2005). Governance and social-economic change in cities. V: Turok, I. (Ed.) Changing Cities: Rethinking Urban Competitiveness, Cohesion and Governance (62-77). London: Routledge.

- Harvey, D. (1989). The Urban Experience. Oxford: Blackwell.

- Hood, C. (1991). A Public Management for All Seasons?. Public Administration 69(1), 3-19.

- Hughes, O. E. (2003). Public management and administration: an introduction. Hampshire: Palgrave.

- Huther, J. \& Shah, A. (1998). Applying a simple measure of good governance to the debate on fiscal decentralization. Washington, DC: World Bank.

- Judd, D. \& Parkinson, M. (1990). Leadership and Urban Regeneration. London: Sage.

- Kaboolian, L. (1998). The new public management: Challenging the boundaries of the management vs. Administration debate. Public Administration Review 58(3), 189-183.

- Keating, M. (1998). The new regionalism in Western Europe: Teritorial restructuring and political change. Cheltenham: Edward Elgar.

- Kettl, D. F. (1995). Building lasting reform: Enduring questions, missing answers. V: Kettl, D. F. \& Diluilo, J. J. (Eds.) Inside the reinvetion machine: appraising governmental reform. Washington DC: Brookings. 
- Korten, D. (1995). When Corporations Rule the World. West Hartford: Kumarian Press.

- Kroukamp, H. \& Lues, L. (2000). Improving local management. V: de Vries, M. S., Reddy, P. S. \& Haque, S. M. Improving local government: Outcomes of Comparative Research (77-92). Hampshire: Palgrave McMillan.

- Le Gales, P. (1998). Regulations and governance in European cities. International Journal of Urban and Regional Research 22(2), 482-506.

- Mayer, M. (1995). Post-fordist city politics V: Ash A. (Ed.) Post-Fordism: A reader (316-337). Oxford: Blackwell.

- Naisbitt, J. (1994). Global Paradox: The Bigger the World Economy, the More Powerful lts Smallest Players. New York: William Morrow \& Co.

- Nethercote, J. R. (1989). The rhetorical tactics of managerialism: reflections on Michaels Keating's apologia, Quo vadis?. Australian Journal of Public Administration 48(4), 363-367.

- Norquist, J. O. (1998). The Wealth of Cities Revitalizing the Center of American Life. New York: Addison Wesley Longman.

- O'Connor, J. (1973). The Fiscal Crisis of the State. New York: St. Martin's Press.

- Offe, C. (1985). Družbena moč in politična oblast: protislovja kapitalistične demokracije - razprave o politični sociologiji poznega kapitalizma. Ljubljana: Delavska enotnost.

- Pollitt, C. (2001). Clarifying convergence: striking similarities and durable differences in public management reform. Public Management Review 4(1), 471-492.

- Pollitt, C. \& Bouckaert, G. (2004). Public management reform: a comparative analysis. Oxford, New York: Oxford University Press.

- Porter, M. E. (1998). On competition. Boston: A Harvard Business Review Book.

- Prohl, M. (Ed.) (1997). International strategies and techniques for future local government. Practical aspects towards innovation and reform. Gutersloh: Bertelsmann Foundation Publishers.

- Prud'homme, R. (1996). The dangers of decentralization. The World Bank Research Observer 10(2), 201-220.

- Rifkin, J. (1995). Konec dela: Zaton svetovne delavske sile in nastop posttržne dobe. Liubliana: Krtina.

- Saunders, P. (1986). Social Theory and the Urban Question. London: Routledge.

134 Uprava, letnik IX, 4/2011 
- Stein, E. (1998). Fiscal decentralization and government size in Latin America. Washington DC: Inter-American Development Bank.

- Stever, J. A. (1988). The End of Public Administration. New York: Ardshley on Hudson.

- Stoker, G. (1996). Redefining Local Democracy. V: Pratchett, L. \& Wilson, D. (Eds.) Local democracy and local government (188-209). Basingstoke: MacMillan.

- Tanzi, V. (1994). Corruption, governmental activities, and markets. Washington, DC: International Monetary Fund.

- Tiebout, C. M. (1956). Apure theory of local expenditures. Journal of Political Economy 5(1), 416-424.

- Urban Audit. (2004). Methodological Handbook: 2004 Edition. Pridobljeno 4. 12. 2008, s http://epp.eurostat.ec.europa.eu/cache/ITY_OFFPUB/KSBD-04-002/EN/KS-BD-04-002-EN.PDF.

- Vlaj, S. (1992). Ustavna in zakonska ureditev lokalne samouprave. Teorija in praksa 29(1-2), 49-59.

- Weikart, L. A. (2001). The Giuliani Administration and the New Public Management in New York City. Urban Affairs Review 36(3), 359-381.

- Žurga, G. (2001). Kakovost državne uprave: pristopi in rešitve. Ljubljana: Fakulteta za družbene vede. 